\title{
OS PERÍMETROS DE PROTEÇÃO SANITÁRIA EM CEMITÉRIOS E SUA IMPORTÂNCIA PARA AS ÁGUAS SUBTERRÂNEAS DE ABASTECIMENTO
}

\author{
A.Pacheco ${ }^{1}$ \\ S.L.Torres ${ }^{2}$
}

Se se considerar que, de uma maneira geral, na implantação de cemitérios não se levam em conta os aspectos geológico e hidrogeológico, este tipo de construção poderá se constituir em unidade de alto potencial de risco para as águas subterrâneas de subsuperfície.

Esta possibilidade é resultante do fato dos cemitérios serem laboratórios de decomposição de matéria orgânica. Com efeito, durante o processo de putrefação proliferam microorganismos degradadores dos corpos, além dos agentes de infecção, quando a morte é por moléstia contagiosa ou epidemia.

Durante os períodos chuvosos, microorganismos patogênicos e vírus podem atingir o lençol freático, se o solo não possuir suficiente capacidade de depuração. Se esta água contaminada fluir para a área externa do cemitério e fôr captada por poços rasos ou através de nascentes, as populações que a consumirem correrão sérios riscos de saúde. Casos históricos registrados na Europa confirmam esta possibilidade. Consequentemente, isto coloca de forma inquestionável a necessidade de maiores cuidados com a localização de cemitérios, de cujos projetos também deverá constar a instalação de um perímetro de proteção sanitária em torno destas construções. Neste deverá ser proibida a presença de habitações e a perfuração de poços.

O presente trabalho é parte de uma pesquisa ampla sobre o problema geoambiental da localização de cemitérios em meio urbano. $O$ mesmo tem por objetivo definir cientificamente o perímetro de proteção sanitária em cemitérios no contexto geológico e hidrogeológico da Região Metropolitana de São Paulo.

\footnotetext{
1Deparatamento de Geologia Econômica e Geofísica Aplicada, Instituto de Geociências, USP.

${ }^{2}$ Bolsa de Iniciação Científica, FAPESP, Deparatamento de Geologia Econômica e Geofísica Aplicada, Instituto de Geociências, USP.
} 